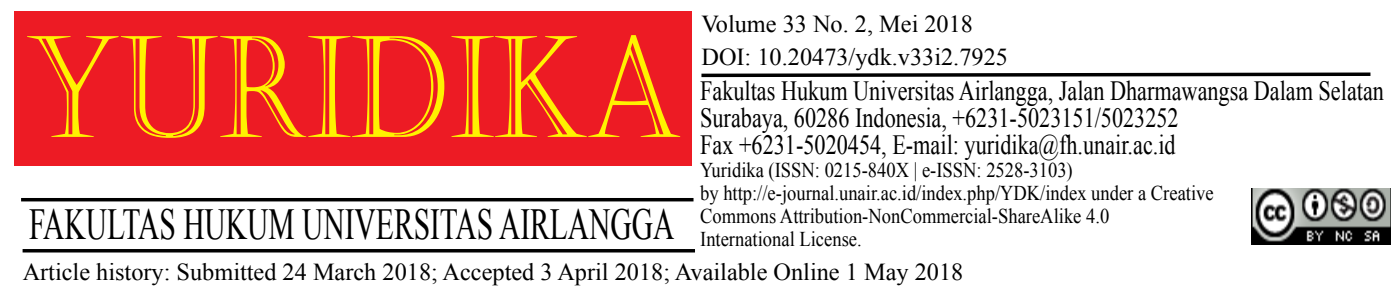

\title{
PEMBEBANAN HAK SEWA UNTUK BANGUNAN ATAS TANAH HAK MILIK: PERSPEKTIF ASAS DAN PEMBUKTIAN
}

\author{
Urip Santoso \\ urip.santoso@fh.unair.ac.id \\ Universitas Airlangga
}

\begin{abstract}
The property land can be used by the owner itselffor the purpose of constructing buildings and/or agricultural, fisheries, livestock, or plantation. This property land can be used by another person with the approval of the owner for the purpose of establishing the building through the grant of rights, or lease. This property land in which there is no the buildings on it can be leased for a certain period by the owner to another parties to establish the buildings. The land for which the holder can lease is the property land. The right to land arising from the lease of right is the right of lease for buildings. The object of right of lease for building is a vacant land that has no building on it that has the ownership status. The origin of the lease land for buildings is the property right. The right of lease for buildings is the imposition of the right of lease for buildings on the property right land. The lease right for buildings is an implementation of the principle of the horizontal separation which is the separation between ownership of land and buildings that is on it. The land deed official are not authorized made the deed the imposition of the lease right for buildings on the property right land as established by article 2 of Government Regulation No. 24 in year 2016.
\end{abstract}

Keywords: Lease of Land; Property Right; Buildings; Horizontal Separation.

\begin{abstract}
Abstrak
Tanah hak milik dapat dipergunakan sendiri oleh pemiliknya untuk keperluan mendirikan bangunan dan atau keperluan pertanian, perikanan, peternakan, atau perkebunan. Tanah hak milik dapat dipergunakan oleh orang lain atas persetujuan dari pemiliknya untuk keperluan mendirikan bangunan melalui pemberian hak, atau sewa menyewa. Tanah hak milik yang tidak ada bangunan di atasnya dapat disewakan untuk jangka tertentu oleh pemiliknya kepada pihak lain guna mendirikan bangunan. Hak atas tanah yang lahir dari penyewaan tanah hak milik adalah hak sewa untuk bangunan. Asal tanah hak sewa untuk bangunan adalah hak milik. Hak sewa untuk bangunan merupakan pembebanan hak sewa untuk bangunan atas tanah hak milik. Hak sewa untuk bangunan merupakan implementasi dari asas pemisahan horizontal yaitu ada pemisahan antara pemilikan atas tanah dan bangunan yang ada di atasnya. Pejabat Pembuat Akta Tanah tidak mempunyai kewenangan membuat akta pembebanan hak sewa untuk bangunan atas tanah hak milik sebagaimana ditetapkan oleh Pasal 2 Peraturan Pemerintah No. 24 Tahun 2016.
\end{abstract}

Kata Kunci: Sewa Tanah; Hak Milik; Bangunan; Pemisahan Horizontal.

\section{Pendahuluan}

Undang-Undang No. 5 Tahun 1960 Tentang Peraturan Dasar Pokok-pokok Agraria, atau dikenal dengan sebutan Undang-Undang Pokok Agraria (selanjutnya disebut UUPA), LNRI Tahun 1960 No. 104-TLNRI No. 2043, diundangkan 
pada tanggal 24 September 1960. UUPA merupakan pelaksanaan Pasal 33 ayat 3 Undang-Undang Dasar Negara Republik Indonesia Tahun 1945 (UUD NRI 1945), sebagaimana dinyatakan dalam Pasal 2 ayat 1 UUPA, yaitu "atas dasar ketentuan dalam Pasal 33 ayat 3 UUD NRI 45 dan hal-hal sebagai yang dimaksud dalam Pasal 1, bumi, air, dan ruang angkasa termasuk kekayaan yang terkandung di dalamnya itu pada tingkatan tertinggi dikuasai oleh Negara sebagai organisasi kekuasaan seluruh rakyat”. Pasal 33 ayat 3 UUD NRI 1945 merupakan landasan konstitusional bagi pembentukan UUPA.

UUPA mempunyai dua substansi dari segi berlakunya, yaitu pertama, mencabut atau menyatakan tidak berlaku peraturan dan keputusan yang dibuat oleh Pemerintah Hindia Belanda, atau tidak memberlakukan Hukum Agraria Kolonial, dan kedua membangun Hukum Agraria Nasional berdasarkan Pancasila dan UUD NRI 1945. Boedi Harsono menyatakan bahwa dengan berlakunya UUPA, maka terjadi perubahan secara fundamental pada Hukum Agraria di Indonesia, terutama hukum di bidang pertanahan. Perubahan yang fundamental ini mengenai struktur perangkat hukum, konsepsi yang mendasari maupun isinya. ${ }^{1}$

UUPA menetapkan hak penguasaan atas tanah adalah serangkaian kewenangan, kewajiban, dan atau larangan bagi pemegang hak penguasaan atas tanah untuk berbuat sesuatu mengenai tanah yang dihaki. Secara hierarki, tata urutan hak penguasaan atas tanah, adalah hak bangsa Indonesia atas tanah, hak menguasai Negara atas tanah, hak ulayat masyarakat hukum adat, dan hak perseorangan atas tanah. Ruang lingkup hak perseorangan atas tanah, meliputi hak atas tanah, wakaf tanah hak milik, hak tanggungan, dan hak milik atas satuan rumah susun.

Salah satu hak penguasaan atas tanah yang bersifat perseorangan adalah hak atas tanah. Hak atas tanah disebutkan dalam Pasal 4 ayat 1 UUPA, yaitu "atas dasar hak menguasai dari Negara sebagai yang dimaksud dalam Pasal 2 ditentukan adanya macam-macam hak atas permukaan bumi, yang disebut tanah, yang dapat

${ }^{1}$ Boedi Harsono, Hukum Agraria Indonesia Sejarah Pembentukan Undang-Undang Pokok Agraria Isi Dan Pelaksanaanya (Djambatan 2003).[1]. 
diberikan kepada dan dipunyai oleh orang-orang baik sendiri maupun bersamasama dengan orang lain serta badan-badan hukum". Hak atas permukaan bumi atau hak atas tanah bersumber dari hak menguasai Negara atas tanah, yang dapat diberikan kepada dan dipunyai oleh perseorangan baik sendiri maupun bersamasama dengan orang lain dan badan-badan hukum.

Boedi Harsono menyatakan bahwa tanah dalam pengertian yuridis menurut UUPA adalah permukaan bumi, sedangkan hak atas tanah adalah hak atas permukaan bumi yang berbatas, berdimensi dua dengan ukuran panjang dan lebar. ${ }^{2}$ Hak atas tanah adalah hak yang memberikan wewenang kepada pemegang haknya untuk mempergunakan tanah dan atau mengambil manfaat dari tanah yang dihaki. ${ }^{3}$ Hak atas tanah yang disebutkan dalam Pasal 4 ayat 1 UUPA dijabarkan macamnya dalam Pasal 16 ayat 1 dan Pasal 53 ayat 1 UUPA. Pasal 16 ayat 1 UUPA menentukan macammacam hak atas tanah, yaitu hak milik, hak guna usaha, hak guna bangunan, hak pakai, hak sewa untuk bangunan, hak membuka tanah, hak memungut hasil hutan dan hak atas tanah yang akan ditetapkan dengan undang-undang. Pasal 53 ayat 1 UUPA menentukan macam-macam hak atas tanah yang bersifat sementara, yaitu hak gadai, hak usaha bagi hasil, hak menumpang dan hak sewa tanah pertanian.

Salah satu hak atas tanah adalah hak milik. Secara rinci, hak milik diatur dalam Pasal 20 sampai dengan Pasal 27 UUPA. Pasal 50 ayat 1 UUPA menetapkan bahwa ketentuan lebih lanjut mengenai hak milik diatur dengan undang-undang. Sampai sekarang undang-undang yang mengatur tentang hak milik belum terbentuk. Pengertian hak milik disebutkan dalam Pasal 20 ayat 1 UUPA, yaitu "hak milik adalah hak turun temurun, terkuat, dan terpenuh yang dapat dipunyai orang atas tanah dengan mengingat ketentuan Pasal 6". Salah satu sifat hak milik adalah terpenuh, artinya hak milik memberi wewenang kepada pemiliknya paling luas bila dibandingkan dengan hak atas tanah yang lain, dapat menjadi induk bagi hak atas tanah yang lain, tidak berinduk pada hak atas tanah yang lain, dan penggunaan

\footnotetext{
${ }^{2}$ ibid. [86].

${ }^{3}$ Urip Santoso, Hukum Agraria Kajian Komprehensif(Kencana Prenada Media Group 2017).[84].
} 
tanahnya lebih luas bila dibandingkan dengan hak atas tanah yang lain. ${ }^{4} \mathrm{Hak}$ milik dapat menjadi induk bagi hak atas tanah yang lain yaitu di atas tanah hak milik dapat lahir hak atas tanah berupa hak guna bangunan, hak pakai, dan hak sewa untuk bangunan. Lahirnya hak guna bangunan, hak pakai dan hak sewa untuk bangunan tidak menghapuskan hak milik. Dengan kata lain, hak milik dapat dibebani hak guna bangunan, hak pakai dan hak sewa untuk bangunan.

Salah satu hak atas tanah yang lahir dari hak milik adalah hak sewa untuk bangunan atau dengan kata lain, hak milik dapat dibebani dengan hak sewa untuk bangunan. Hak sewa untuk bangunan disebutkan dalam Pasal 16 ayat 1 huruf e UUPA dan diatur dalam Pasal 44 dan Pasal 45 UUPA. Tanah hak milik yang tidak ada bangunan di atasnya dapat disewakan untuk jangka waktu tertentu oleh pemiliknya kepada pihak lain. Hak atas tanah yang lahir dari penyewaan tanah hak milik adalah hak sewa untuk bangunan. Dari uraian pendahuluan di atas dapat dikaji permasalahan yang dirumuskan, yaitu: asas dalam pembebanan hak sewa untuk bangunan atas tanah hak milik dan pembuktian dalam pembebanan hak sewa untuk bangunan atas tanah hak milik.

\section{Pengaturan Pembebanan Hak Sewa Untuk Bangunan Atas Tanah Hak Milik}

Hak sewa untuk bangunan disebutkan dalam Pasal 16 ayat 1 huruf e UUPA. Secara khusus hak sewa untuk bangunan diatur dalam Pasal 44 dan Pasal 45 UUPA. Menurut Pasal 50 ayat 2 UUPA, ketentuan lebih lanjut mengenai hak guna usaha, hak guna bangunan, hak pakai dan hak sewa untuk bangunan diatur dengan peraturan perundangan. Peraturan perundangan yang secara khusus mengatur hak sewa untuk bangunan sebagaimana dimaksudkan oleh Pasal 50 ayat 2 UUPA sampai sekarang belum terbentuk. Dalam pembidangan hak atas tanah, hak sewa untuk bangunan merupakan salah satu hak atas tanah yang bersifat tetap, yaitu hak atas tanah ini akan tetap ada selama UUPA masih berlaku atau belum diganti dengan undang-undang yang baru. Selain UUPA, hak atas tanah yang

${ }^{4}$ ibid.[92-93]. 
bersifat tetap, yaitu hak milik, hak guna usaha, hak guna bangunan, hak pakai, hak membuka tanah dan hak memungut hasil hutan.

Dari aspek asal tanahnya, hak atas tanah dibagi menjadi dua, yaitu pertama, hak atas tanah yang bersifat primer adalah hak atas tanah yang berasal dari tanah Negara. Hak atas tanah yang bersifat primer, yaitu meliputi hak milik, hak guna usaha, hak guna bangunan atas tanah negara dan hak pakai tanah negara. Kedua, hak atas tanah yang bersifat sekunder adalah hak atas tanah yang berasal dari tanah pihak lain. Hak atas tanah yang bersifat sekunder, meliputi hak guna bangunan atas tanah hak pengelolaan, hak guna bangunan atas tanah hak milik, hak pakai tanah hak pengelolaan, hak pakai atas tanah hak milik, hak sewa untuk bangunan, hak gadai, hak usaha bagi hasil, hak menumpang, dan hak sewa tanah pertanian. ${ }^{5}$ Hak sewa untuk bangunan merupakan hak atas tanah yang bersifat sekunder disebabkan asal tanah hak sewa untuk bangunan adalah tanah hak milik.

UUPA menyebut hak sewa untuk bangunan, sedangkan Pasal 44 ayat 1 Peraturan Pemerintah No. 24 Tahun 1997 Tentang Pendaftaran Tanah (selanjutnya disebut Peraturan Pemerintah No. 24 Tahun 1997) mengatur pembebanan hak sewa untuk bangunan atas tanah hak milik. Pembebanan hak sewa untuk bangunan merupakan hak milik yang dibebani hak sewa untuk bangunan. Hak sewa untuk bangunan adalah hak atas tanah yang lahir dari tanah hak milik. UUPA tidak memberikan pengertian hak sewa untuk bangunan. Pasal 44 ayat 1 UUPA menyatakan bahwa seseorang atau suatu badan hukum mempunyai hak sewa atas tanah, apabila ia berhak menggunakan tanah milik orang lain untuk keperluan bangunan dengan membayar kepada pemiliknya sejumlah uang sebagai sewa.

Hak sewa untuk bangunan adalah hak yang dimiliki seseorang atau badan hukum untuk mendirikan dan mempunyai bangunan di atas tanah hak milik orang lain dengan membayar sejumlah uang sebagai sewa dan dalam jangka waktu tertentu untuk menggunakan tanah berdasarkan kesepakatan antara pemilik tanah dan pemegang hak sewa untuk bangunan. Dalam hak sewa untuk bangunan, pemilik

\footnotetext{
${ }^{5}$ Urip Santoso, Perolehan Hak Atas Tanah (Kencana Prenada Media Group 2015).[31].
} 
tanah menyerahkan tanahnya dalam keadaan kosong kepada penyewa tanah dengan maksud agar penyewa dapat mendirikan bangunan di atas tanah tersebut. Bangunan itu menurut hukum menjadi milik penyewa, kecuali ada perjanjian lain. ${ }^{6}$ Pada hak sewa untuk bangunan, objek sewa menyewanya adalah tanah kosong yang berstatus hak milik yang disewa oleh penyewa tanah untuk jangka waktu tertentu dengan membayar sejumlah uang sebagai sewa.

Pasal 45 UUPA menetapkan bahwa yang dapat menjadi pemegang hak sewa untuk bangunan, adalah warga negara Indonesia, orang asing yang berkedudukan di Indonesia, badan hukum yang didirikan menurut hukum Indonesia dan berkedudukan di Indonesia, dan badan hukum asing yang mempunyai perwakilan di Indonesia. Pemegang hak sewa untuk bangunan dapat berupa perseorangan yang berasal dari warga negara Indonesia atau orang asing yang berkedudukan di Indonesia, atau berupa badan hukum yaitu badan hukum privat atau badan hukum publik yang berasal dari badan hukum yang didirikan menurut hukum Indonesia dan berkedudukan di Indonesia atau badan hukum asing yang mempunyai perwakilan di Indonesia.

Pasal 44 ayat 2 UUPA menetapkan bahwa pembayaran uang sewa dapat dilakukan satu kali atau pada tiap-tiap waktu tertentu, atau sebelum atau sesudah tanahnya digunakan. Pasal tersebut menetapkan bahwa ketentuan mengenai uang sewa dalam hak sewa untuk bangunan, yaitu:

1. uang sewa dibayar sekali oleh pemegang hak sewa untuk bangunan selama hak sewa untuk bangunan berlangsung;

2. uang sewa dibayar oleh pemegang hak sewa untuk bangunan pada waktu-waktu tertentu selama hak sewa untuk bangunan berlangsung;

3. uang sewa dibayar oleh pemegang hak sewa untuk bangunan sebelum hak sewa untuk bangunan terjadi; atau

4. uang sewa dibayar oleh pemegang hak sewa untuk bangunan setelah hak sewa untuk bangunan terjadi.

Ketentuan mengenai pembayaran uang sewa dalam hak sewa untuk bangunan oleh pemegang hak sewa untuk bangunan kepada pemilik tanah bergantung pada

${ }^{6}$ Sudikno Mertokusumo, Hukum Dan Politik Agraria (Karunika 1988).[25]. 
kesepakatan antara pemilik tanah dan pemegang hak sewa untuk bangunan yang dituangkan dalam perjanjian kedua belah pihak.

Pada Pasal 44 UUPA tidak mengatur jangka waktu hak sewa untuk bangunan. Oleh karena penggunaan tanah hak milik oleh pihak lain guna keperluan mendirikan bangunan dengan pembayaran sejumlah uang sebagai sewa, maka hak sewa untuk bangunan mempunyai jangka waktu tertentu. Jangka waktu hak sewa untuk bangunan berdasarkan kesepakatan antara pemilik tanah dan pemegang hak sewa untuk bangunan. Pasal tersebut juga tidak mengatur setelah berakhirnya jangka waktu hak sewa untuk bangunan. Hak sewa untuk bangunannya dapat diperpanjang jangka waktunya ataukah diperbaharui haknya. Ada tidaknya perpanjangan jangka waktu hak sewa untuk bangunan ataukah pembaharuan hak sewa untuk bangunan bergantung pada kesepakatan antara pemilik tanah dan pemegang hak sewa untuk bangunan yang dituangkan dalam perjanjian kedua belah pihak.

Kesepakatan untuk perpanjangan jangka waktu atau pembaharuan hak sewa untuk bangunan dapat dilakukan diawal terjadinya hak sewa untuk bangunan atau setelah jangka waktu hak sewa untuk bangunannya berakhir. Pasal 44 UUPA tidak mengatur peralihan hak sewa untuk bangunan. Oleh karena hak sewa untuk bangunan itu merupakan suatu hak, maka hak sewa untuk bangunan dapat beralih dan dialihkan oleh pemegang haknya kepada pihak lain. Kata "dapat" beralih dan dialihkan pada hak sewa untuk bangunan menunjukkan bahwa dapat tidaknya hak sewa untuk bangunan beralih dan dialihkan oleh pemegang haknya kepada pihak lain bergantung pada kesepakatan antara pemilik tanah dan pemegang hak sewa untuk bangunan yang dituangkan dalam perjanjian kedua belah pihak.

Peralihan hak sewa untuk bangunan dibuktikan dengan perjanjian tertulis antara pemilik tanah dan pemegang hak sewa untuk bangunan, yang dapat berbentuk akta di bawah tangan, atau akta autentik, yaitu akta notaris atau akta Pejabat Pembuat Akta Tanah (selanjutnya disebut PPAT). Pasal 44 UUPA tidak mengatur hak sewa untuk bangunan dapat dijadikan jaminan utang. UUPA menetapkan bahwa hak milik, hak guna usaha dan hak guna bangunan dapat dijadikan jaminan utang dengan dibebani hak tanggungan. Undang-Undang No. 4 Tahun 1996 Tentang 
Hak Tanggungan Atas Tanah Beserta Benda-Benda Yang Berkaitan Dengan Tanah (selanjutnya disebut UUHT) menetapkan bahwa hak yang dapat dijadikan jaminan utang dengan dibebani hak tanggungan adalah hak milik, hak guna usaha, hak guna bangunan, hak pakai yang menurut ketentuannya wajib didaftarkan dan menurut sifatnya dapat dipindahtangankan dan hak milik atas satuan rumah susun.

UUPA dan UUHT tidak menetapkan bahwa hak sewa untuk bangunan dapat dijadikan jaminan utang dengan dibebani hak tanggungan. Hak sewa untuk bangunan tidak dapat dijadikan jaminan utang dengan dibebani hak tanggungan disebabkan tidak memenuhi persyaratan yang ditetapkan oleh UUHT. Pada hak sewa untuk bangunan terdapat pemisahan dalam pemilikan tanah dan pemilikan bangunan di atas tanah hak milik. Tanahnya adalah milik pemilik tanah, sedangkan bangunan adalah milik pemegang hak sewa untuk bangunan. Bangunan pada hak sewa untuk bangunan mempunyai nilai ekonomis yang dapat dinilai dengan uang sehingga dapat dijadikan jaminan utang. Bangunan pada hak sewa untuk bangunan dapat dijadikan jaminan utang apabila ada persetujuan dari pemilik tanah disebabkan tanah pada hak sewa untuk bangunan terikat dengan tanah hak milik orang lain. Lembaga jaminan yang dapat mewadahi bangunan pada hak sewa untuk bangunan dijadikan jaminan utang adalah jaminan fidusia.

Jaminan fidusia diatur dalam Undang-Undang No. 42 Tahun 1999 Tentang Jaminan Fidusia, LNRI Tahun 1999 No. 166-TLNRI No. 3889, disahkan pada tanggal 30 September 1999 (selanjutnya disebut UU No. 42 Tahun 1999). Pengertian fidusia disebutkan dalam Pasal 1 angka 1 Undang-Undang No. 42 Tahun 1999, yaitu pengalihan hak kepemilikan suatu benda atas dasar kepercayaan dengan ketentuan bahwa benda yang kepemilikannya dialihkan tersebut tetap dalam penguasaan pemilik benda. Pengertian jaminan fidusia disebutkan dalam Pasal 1 angka 2 Undang-Undang No. 42 Tahun 1999, yaitu hak jaminan atas benda bergerak, baik berwujud maupun yang tidak berwujud dan benda tidak bergerak khususnya bangunan yang tidak dapat dibebani hak tanggungan sebagaimana dimaksud dalam Undang-Undang Nomor 4 Tahun 1996 Tentang Hak Tanggungan Atas Tanah Beserta Benda-Benda Yang Berkaitan Dengan Tanah (selanjutanya 
disebut UU Nomor 4 Tahun 1996), akan tetap berada dalam penguasaan pemberi fidusia, sebagai agunan bagi pelunasan utang tertentu, yang memberi kedudukan yang diutamakan kepada penerima fidusia terhadap kreditor lainnya.

Bangunan pada hak sewa untuk bangunan termasuk objek jaminan fidusia disebabkan hak sewa untuk bangunan tidak termasuk objek hak tanggungan sebagaimana ditetapkan dalam UUPA dan Undang-Undang Nomor 4 Tahun 1996. Pasal 44 UUPA tidak mengatur hapusnya hak sewa untuk bangunan. Faktor-faktor yang dapat menjadi penyebab hapusnya hak sewa untuk bangunan adalah jangka waktunya berakhir, dihentikan sebelum jangka waktunya berakhir disebabkan pemegang hak sewa untuk bangunan tidak memenuhi kewajiban yang diperjanjikan dengan pemilik tanah, pemegang hak sewa untuk bangunan meninggal dunia, hak milik dilepaskan oleh pemiliknya, hak milik dicabut untuk kepentingan umum atau tanahnya musnah. Ketentuan-ketentuan dalam hak sewa untuk bangunan yang diatur dalam UUPA, yaitu:

1. pemilik tanah menyewakan tanah hak miliknya tanpa bangunan di atasnya kepada penyewa tanah atau pemegang hak sewa untuk bangunan;

2. hak sewa untuk bangunan terjadi dengan perjanjian antara pemilik tanah dan pemegang hak sewa untuk bangunan;

3. pemegang hak sewa untuk bangunan berhak mendirikan bangunan di atas tanah yang disewanya;

4. pemegang hak sewa untuk bangunan wajib membayar uang sewa tanah kepada pemilik tanah yang besarnya berdasarkan kesepakatan kedua belah pihak.

5. hak sewa untuk bangunan berjangka waktu tertentu;

6. pemegang hak sewa untuk bangunan adalah perseorangan dan badan hukum yang didirikan menurut hukum Indonesia dan berkedudukan di Indonesia.

7. hak sewa untuk bangunan tidak dapat dialihkan kepada pihak lain kecuali ada persetujuan dari pemilik tanah;

8. hak sewa untuk bangunan tidak dapat dijadikan jaminan utang dengan dibebani fidusia kecuali ada persetujuan dari pemilik tanah;

9. hak sewa untuk bangunan hapus dengan berakhirnya jangka waktu hak sewa untuk bangunan kecuali ada kesepakatan kedua belah pihak untuk perpanjangan jangka waktu atau pembaharuan hak sewa untuk bangunan.

\section{Asas Dalam Pembebanan Hak Sewa Untuk Bangunan Atas Tanah Hak Milik}

Djuhaendah Hasan menyatakan bahwa ada dua macam asas hubungan hukum antara tanah dengan benda lain yang melekat padanya, yaitu: pertama, asas 
perlekatan vertikal (verticale accessie beginsel) adalah asas yang mendasarkan pemilikan tanah dan segala benda yang melekat padanya sebagai suatu kesatuan yang tertancap menjadi satu. ${ }^{7}$ Asas perlekatan vertikal diartikan bahwa pemilikan atas tanah berarti juga memiliki bangunan atau rumah dan segala sesuatu yang melekat pada tanah itu. ${ }^{8}$ Kedua, asas pemisahan horizontal (horizontale scheiding van beginsel), adalah memisahkan tanah dari segala sesuatu yang melekat pada tanah tersebut. ${ }^{9}$ Berdasarkan asas pemisahan horizontal, pemilikan atas tanah dan benda atau segala sesuatu yang berada di atas tanah adalah terpisah. ${ }^{10}$

Ada dua macam asas hubungan hukum antara orang dengan tanah, yaitu: pertama, asas perlekatan (accessie beginsel). Dalam asas ini, bangunan dan tanaman yang ada di atas tanah merupakan satu kesatuan, bangunan atau tanaman tersebut bagian dari tanah yang bersangkutan. Hak atas tanah dengan sendiri karena hukum meliputi juga pemilikan bangunan dan tanaman yang ada di atas tanah yang dihaki, kecuali kalau ada kesepakatan lain dengan pihak yang membangun atau menanamnya. Kedua, asas pemisahan horizontal (horizontale scheiding van beginsel). Dalam asas ini, bangunan dan tanaman yang ada di atas tanah bukan merupakan satu kesatuan. Hak atas tanah dengan sendiri karena hukum tidak dengan sendirinya meliputi pemilikan bangunan dan tanaman yang ada di atasnya. Perbuatan hukum mengenai tanah tidak dengan sendirinya meliputi bangunan dan tanaman yang ada di atasnya. Jika perbuatan hukumnya dimaksudkan meliputi bangunan dan tanaman yang ada di atasnya, maka hal itu secara tegas harus dinyatakan dalam akta yang membuktikan dilakukannya perbuatan hukum yang bersangkutan. ${ }^{11}$

Eman menyatakan bahwa ada dua macam asas hubungan hukum dalam pemilikan atas tanah, yaitu: pertama, dalam asas perlekatan memberikan kewenangan kepada pemilik tanah untuk menggunakan tanahnya juga berkewenangan pula

\footnotetext{
${ }^{7}$ Djuhaendah Hasan, Lembaga Jaminan Kebendaan Dan Benda Lain Yang Melekat Pada Tanah Dalam Konsepsi Penerapan Asas Pemisahan Horizontal (Citra Aditya Bakti 1996).[65].

${ }^{8}$ ibid. [73].

${ }^{9}$ ibid.[65].

${ }^{10}$ ibid.[76].

${ }^{11}$ Urip Santoso, Hukum Agraria Kajian Komprehensif. Op.Cit.[12].
} 
terhadap ruang udara di atasnya serta berhak ruang bawah tanah. ${ }^{12}$ Kedua, dengan adanya asas pemisahan horizontal ini, subjek pemegang hak atas tanahnya bisa berbeda dengan subjek atas kepemilikan bangunan gedung. Demikian pula, tanah dan bangunannya akan tunduk pada hukum yang berbeda, tanah akan tunduk pada hukum tanah, sedangkan bangunannya akan tunduk pada hukum perhutangan yang mengatur penguasaan hak atas benda bukan tanah. ${ }^{13}$

Iman Sudijat menyatakan bahwa asas pemisahan horizontal adalah pemilikan atas tanah dan benda atau segala sesuatu yang berdiri di atas tanah itu adalah terpisah. Asas pemisahan horizontal memisahkan tanah dengan benda lain yang melekat pada tanah itu. Dalam kaitannya dengan ini, Ter Haar yang pendapatnya dikutip oleh Iman Sudijat menyatakan bahwa tanah adalah terpisah dari segala sesuatu yang melekat padanya atau pemilikan atas tanah terlepas dari benda yang ada di atas itu sehingga pemilik tanah dan bangunan yang berada di atasnya dapat berbeda. ${ }^{14}$

Ketentuan dalam asas pemisahan horizontal, adalah tanah dan benda-benda yang ada di atasnya (bangunan atau tanaman) bukan merupakan satu kesatuan, pemilikan atas tanah tidak selalu memiliki benda-benda (bangunan atau tanaman) yang ada di atasnya, dan perbuatan hukum mengenai tanah tidak selalu termasuk benda-benda (bangunan atau tanaman) yang ada di atasnya. Pada hak sewa untuk bangunan terdapat pemisahan dalam pemilikan tanah dan bangunan. Tanah yang berstatus hak milik adalah milik dari pemilik tanah, sedangkan bangunan yang ada di atas tanah hak milik adalah milik pemegang hak sewa untuk bangunan. Hak sewa untuk bangunan merupakan implementasi dari asas pemisahan horizontal (horizontale scheiding van beginsel).

Ketentuan dalam asas pemisahan horizontal pada hak sewa untuk bangunan, yaitu: a) tanah hak milik adalah milik dari pemilik tanah, b) bangunan di atas tanah hak milik adalah milik dari pemegang hak sewa untuk bangunan, c) tanah hak milik

\footnotetext{
${ }^{12}$ Eman, 'Asas Pemisahan Horizontal Dalam Hukum Tanah Nasional', Pidato Pengukuhan Jabatan Guru Besar (Fakultas Hukum Universitas Airlangga 2008).[6].

13 ibid. [9].

${ }^{14}$ Iman Sudijat, Hukum Adat Sketsa Asas (Liberty 1981).[84].
} 
yang sedang dibebani hak sewa untuk bangunan tidak dapat dialihkan melalui jual beli, tukar menukar, atau hibah oleh pemilik tanah kepada pihak lain kecuali ada persetujuan dari pemegang hak sewa untuk bangunan, d) tanah hak milik yang sedang dibebani hak sewa untuk bangunan tidak dapat dijadikan jaminan utang dengan dibebani hak tanggungan oleh pemilik tanah kecuali ada persetujuan dari pemegang hak sewa untuk bangunan, e) pemegang hak sewa untuk bangunan tidak dapat mengalihkan bangunan di atas tanah hak milik melalui jual beli, tukar menukar, atau hibah kepada pihak lain kecuali ada persetujuan dari pemilik tanah, f) pemegang hak sewa untuk bangunan tidak dapat menjadikan bangunan di atas tanah hak milik sebagai jaminan utang dengan dibebani fidusia kecuali ada persetujuan dari pemilik tanah. Selain hak sewa untuk bangunan, hak atas tanah yang merupakan implementasi dari asas pemisahan horizontal, adalah hak guna bangunan atas tanah hak pengelolaan, hak guna bangunan atas tanah hak milik, hak pakai atas tanah hak pengelolaan dan hak pakai atas tanah hak milik.

\section{Pembuktian Dalam Pembebanan Hak Sewa Untuk Bangunan Atas Tanah Hak Milik}

Pembuktian yang sempurna dalam hak penguasaan atas tanah sebagai hasil dari pendaftaran tanah adalah sertipikat. Pengertian sertipikat disebutkan dalam Pasal 1 angka 20 Peraturan Pemerintah No. 24 Tahun 1997, yaitu surat tanda bukti hak sebagaimana dimaksud dalam Pasal 19 ayat 2 huruf c UUPA untuk hak atas tanah, hak pengelolaan, tanah wakaf, hak milik atas satuan rumah susun, dan hak tanggungan yang masing-masing dibukukan dalam buku tanah yang bersangkutan. Berdasarkan pengertian sertipikat dan objek pendaftaran tanah sebagaimana ditetapkan dalam Pasal 9 Peraturan Pemerintah No. 24 Tahun 1997 diterbitkan macam-macam sertipikat, yaitu sertipikat hak milik, sertipikat hak guna usaha, sertipikat hak guna bangunan, sertipikat hak pakai, sertipikat hak pengelolaan, sertipikat tanah wakaf, sertipikat hak milik atas satuan rumah susun, dan sertipikat hak tanggungan.

Pasal 44 ayat 3 UUPA menyatakan bahwa perjanjian sewa tanah yang dimaksudkan dalam pasal ini tidak boleh disertai syarat-syarat yang mengandung 
unsur-unsur pemerasan. Berdasarkan ketentuan Pasal 44 ayat 3 UUPA, pembebanan hak sewa untuk bangunan atas tanah hak milik terjadi dengan perjanjian antara pemilik tanah dan pemegang hak sewa untuk bangunan. Oleh karena terjadinya hak sewa untuk bangunan dengan perjanjian, maka harus ada kesepakatan antara pemilik tanah dan pemegang hak sewa untuk bangunan. Dalam Pasal 44 ayat 3 UUPA tidak menetapkan bentuk perjanjiannya tertulis ataukah tidak, sifat perjanjiannya dibuat dengan akta di bawah tangan ataukah dengan akta notaris atau akta PPAT. Pasal 44 ayat 3 UUPA hanya menetapkan bahwa dalam perjanjian terjadinya hak sewa untuk bangunan tidak boleh disertai syarat-syarat yang mengandung unsur-unsur pemerasan. Tidak boleh ada pemerasan oleh pemilik tanah kepada pemegang hak sewa untuk bangunan atau sebaliknya.

Pengertian perjanjian menurut Pasal 1313 Burgerlijk Wetboek (BW) adalah suatu perbuatan dengan mana satu orang atau lebih mengikatkan dirinya terhadap satu orang lain atau lebih. Subekti menyatakan bahwa perjanjian adalah suatu peristiwa dimana seorang berjanji untuk melaksanakan sesuatu hal. Dari peristiwa itu timbulah suatu hubungan antara dua orang tersebut yang dinamakan perikatan. ${ }^{15}$ Subekti memberikan pengertian perikatan adalah suatu hubungan hukum (mengenai harta kekayaan) antara dua orang yang memberi hak pada yang satu untuk menuntut barang sesuatu yang lainnya, sedangkan orang yang lainnya ini diwajibkan memenuhi tuntutan itu. ${ }^{16}$ Perjanjian adalah suatu hubungan hukum antara dua orang atau lebih yang menimbulkan hak dan kewajiban bagi para pihak.

Perjanjian untuk terjadinya pembebanan hak sewa untuk bangunan atas tanah hak milik memuat hak dan kewajiban bagi pemilik tanah dan pemegang hak sewa untuk bangunan. Hak bagi pemilik tanah adalah menerima sejumlah uang sebagai uang sewa dari pemegang hak sewa untuk bangunan dan menerima kembali tanah hak miliknya setelah jangka waktu hak sewa untuk bangunan berakhir. Kewajiban bagi pemilik tanah adalah menyerahkan tanah hak miliknya kepada pemegang hak sewa untuk bangunan untuk jangka waktu tertentu. Hak

\footnotetext{
${ }^{15}$ Subekti, Hukum Perjanjian (Intermasa 2014).[1].

${ }^{16}$ Subekti, Pokok-Pokok Hukum Perikatan (Jakarta 1987).[187].
} 
bagi pemegang hak sewa untuk bangunan adalah mempergunakan tanah hak milik orang lain dalam hubungan sewa menyewa tanah dalam jangka waktu tertentu dan mendirikan bangunan di atas tanah hak milik orang lain. Kewajiban bagi pemegang hak sewa untuk bangunan adalah membayar uang sewa tanah kepada pemilik tanah dan menyerahkan kembali tanah yang disewanya setelah jangka waktu sewa menyewa tanah berakhir.

Dalam peraturan peraturan perundang-undangan ditetapkan bahwa ada empat cara perolehan hak atas tanah, yaitu pertama, penetapan pemerintah yaitu perolehan hak atas tanah yang berasal dari tanah negara atau hak pengelolaan yang diterbitkan Surat Keputusan Pemberian Hak (SKPH) oleh Menteri Agraria dan Tata Ruang atau Kepala Badan Pertanahan Nasional, atau dilimpahkan kepada Kantor Wilayah Badan Pertanahan Nasional Provinsi atau Kepala Kantor Pertanahan Kabupaten atau Kota. Kedua, ketentuan undang-undang (Penegasan Konversi), yaitu perolehan hak milik yang berasal dari bekas tanah milik adat. Ketiga, peralihan hak yaitu perolehan hak atas tanah yang berasal dari beralih melalui pewarisan, atau dialihkan melalui jual beli, tukar menukar, hibah, penyertaan dalam modal perusahaan (inbreng). Keempat, pemberian hak yaitu perolehan hak atas tanah yang berasal dari pemberian hak guna bangunan atau hak pakai atas tanah hak milik yang dibuktikan dengan akta PPAT yang berwenang.

Dari keempat cara perolehan hak atas tanah di atas, hak sewa untuk bangunan merupakan hak atas tanah yang diperoleh melalui pemberian hak, yaitu pemberian hak oleh pemilik tanah kepada penyewa tanah sebagai pemegang hak sewa untuk bangunan. Perolehan hak sewa untuk bangunan sama seperti perolehan hak guna bangunan atau hak pakai atas tanah hak milik, yaitu dengan pemberian hak oleh pemilik tanah kepada pemegang hak guna bangunan atau hak pakai atas tanah. Perolehan hak sewa untuk bangunan terjadi didahului oleh perjanjian antara pemilik tanah dan pemegang hak sewa untuk bangunan.

Terjadinya pembebanan hak sewa untuk bangunan atas tanah hak milik harus memenuhi dua syarat sahnya, yaitu pertama, syarat materiil yaitu pemilik tanah berhak dan berwenang menyewakan tanah hak miliknya kepada orang lain, sedangkan 
penyewa tanah harus memenuhi syarat sebagai subjek hak sewa untuk Bangunan. Kedua, syarat formal yaitu pembebanan hak sewa untuk bangunan atas tanah hak milik harus dibuktikan dengan perjanjian dan apabila pembebanan hak sewa untuk bangunan atas tanah hak milik ingin didaftarkan Kantor Pertanahan Kabupaten/Kota maka harus dibuktikan dengan akta yang dibuat oleh PPAT yang berwenang.

UUPA hanya mengatur bahwa hak sewa untuk bangunan dibuat dengan perjanjian antara pemilik tanah dan pemegang hak sewa untuk bangunan, tidak mengatur pembuktian perjanjian terjadinya hak sewa untuk bangunan. Pasal 44 ayat 1 Peraturan Pemerintah No. 24 Tahun 1997 mengatur pembuktian dan pendaftaran hak sewa untuk bangunan yaitu: "pembebanan hak tanggungan pada hak atas tanah atau hak milik atas satuan rumah susun, pembebanan hak guna bangunan, hak pakai, dan hak sewa untuk bangunan atas hak milik, dan pembebanan lain pada hak atas tanah atau hak milik atas satuan rumah susun yang ditentukan dengan peraturan perundang-undangan, dapat didaftar jika dibuktikan dengan akta yang dibuat oleh PPAT yang berwenang menurut ketentuan peraturan perundang-undangan yang berlaku”. Berdasarkan ketentuan Pasal 44 ayat 1 Peraturan Pemerintah No. 24 Tahun 1997, pembebanan hak sewa untuk bangunan atas tanah hak milik dapat didaftarkan ke Kantor Pertanahan Kabupaten/Kota apabila dibuktikan dengan akta PPAT yang berwenang. Dengan demikian, kalau pembebanan hak sewa untuk bangunan atas tanah hak milik tidak untuk didaftarkan ke Kantor Pertanahan Kabupaten/Kota, maka pembebanan hak sewa untuk bangunan atas tanah hak milik boleh dibuktikan dengan akta yang tidak dibuat oleh PPAT.

Dari aspek tanda bukti hak dalam pembebanan hak sewa untuk bangunan atas tanah hak milik. Tanda bukti hak milik berupa sertipikat hak milik atau kutipan atau Register Leter C, sedangkan tanda bukti kepemilikan bangunan pada hak sewa untuk bangunan menurut Undang-Undang No. 28 Tahun 2002 Tentang Bangunan Gedung juncto Peraturan Pemerintah No. 36 Tahun 2005 Tentang Peraturan Pelaksanaan Undang-Undang Nomor 28 Tahun 2002 Tentang Bangunan Gedung berupa surat tanda bukti kepemilikan bangunan gedung yang diterbitkan oleh Pemerintah Kabupaten/Kota. Penerbitan surat 
tanda bukti kepemilikan bangunan gedung yang diperintahkan oleh UndangUndang No. 28 Tahun 2002 juncto Peraturan Pemerintah No. 36 Tahun 2005 sampai sekarang belum dibentuk.

Maksud pendaftaran pembebanan hak sewa untuk bangunan atas tanah Hak milik ke Kantor Pertanahan Kabupaten/Kota adalah agar dicatat dalam buku tanah hak milik yang dibebani hak sewa untuk bangunan sehingga terwujud jaminan kepastian hukum, perlindungan hukum, dan tertib administrasi pertanahan. Meskipun pembebanan hak sewa untuk bangunan atas tanah hak milik didaftarkan ke Kantor Pertanahan Kabupaten/Kota, namun tidak diterbitkan sertipikat hak sewa untuk bangunan sebagai tanda bukti haknya disebabkan berdasarkan ketentuan dalam Pasal 9 Peraturan Pemerintah No. 24 Tahun 1997 ditetapkan bahwa hak sewa untuk bangunan tidak termasuk objek pendaftaran tanah.

Untuk memberikan jaminan kepastian hukum, perlindungan hukum, dan tertib administrasi pertanian, sebaiknya bentuk perjanjian untuk terjadinya pembebanan hak sewa untuk bangunan atas tanah hak milik dibuat secara tertulis dan sifat perjanjiannya dengan akta notaris atau akta PPAT. Kalau bentuk perjanjian untuk terjadinya hak sewa untuk bangunan dibuat secara tidak tertulis dan sifat perjanjiannya dengan akta di bawah tangan dapat diingkari oleh para pihak apabila di kemudian hari timbul sengketa antara pemilik tanah dan pemegang hak sewa untuk bangunan.

Berdasarkan ketentuan Pasal 44 ayat 1 Peraturan Pemerintah No. 24 Tahun 1997, hak sewa untuk bangunan termasuk objek pendaftaran tanah. Pasal 9 Peraturan Pemerintah No. 24 Tahun 1997 menetapkan bahwa objek pendaftaran tanah, meliputi hak milik, hak guna usaha, hak guna bangunan, hak pakai, tanah hak pengelolaan, tanah wakaf, hak milik atas satuan rumah susun, hak tanggungan dan tanah negara.

Berdasarkan ketentuan Pasal 9 Peraturan Pemerintah No. 24 Tahun 1997, hak sewa untuk bangunan tidak termasuk objek pendaftaran tanah atau hak atas tanah yang tidak wajib didaftarkan ke Kantor Pertanahan Kabupaten/Kota. Namun demikian, Pasal 44 ayat 1 Peraturan Pemerintah No. 24 Tahun 1997 menetapkan bahwa pembebanan hak sewa untuk bangunan atas tanah hak milik dapat didaftarkan 
ke Kantor Pertanahan Kabupaten/Kota jika dibuktikan dengan akta PPAT yang berwenang. Ada ketidaksinkronan antara Pasal 9 Peraturan Pemerintah No. 24 Tahun 1997 dan Pasal 44 ayat 1 Peraturan Pemerintah No. 24 Tahun 1997, yaitu Pasal 9 Peraturan Pemerintah No. 24 Tahun 1997 menetapkan bahwa hak sewa untuk bangunan tidak termasuk objek pendaftaran tanah atau hak atas tanah yang tidak wajib didaftarkan ke Kantor Pertanahan Kabupaten/Kota, sedangkan Pasal 44 ayat 1 Peraturan Pemerintah No. 24 Tahun 1997 menetapkan bahwa hak sewa untuk bangunan dapat didaftarkan ke Kantor Pertanahan Kabupaten/Kota jika dibuktikan dengan akta PPAT yang berwenang.

Pasal 44 ayat 1 Peraturan Pemerintah No. 24 Tahun 1997 juga tidak sinkron dengan Pasal 2 Peraturan Pemerintah No. 24 Tahun 2016 Tentang PPAT (selanjutnya disebut Peraturan Pemerintah No. 24 Tahun 2016). Pasal 44 ayat 1 Peraturan Pemerintah No. 24 Tahun 1997 menetapkan bahwa hak sewa untuk bangunan dapat didaftarkan ke Kantor Pertanahan Kabupaten atau Kota jika dibuktikan dengan akta PPAT yang berwenang sedangkan Pasal 2 Peraturan Pemerintah No. 24 Tahun 2016 menetapkan bahwa PPAT tidak berwenang membuat akta hak sewa untuk bangunan. Akta-akta yang kewenangannya dibuat oleh PPAT berdasarkan Pasal 2 Peraturan Pemerintah No. 24 Tahun 2016, adalah akta jual beli, akta tukar menukar, akta hibah, akta penyertaan dalam modal perusahaan, akta pemberian hak guna bangunan atas tanah hak milik, akta pemberian hak pakai atas tanah hak milik, akta pemberian hak tanggungan dan akta kuasa membebankan hak tanggungan.

PPAT dilarang membuat akta di luar kewenangan yang ditetapkan oleh Peraturan Pemerintah No. 24 Tahun 2016. Akta-akta yang kewenangannya diserahkan kepada PPAT sudah ditetapkan secara tegas dalam Peraturan Pemerintah No. 24 Tahun 2016. PPAT yang membuat akta di luar kewenangan yang ditetapkan oleh Peraturan Pemerintah No. 24 Tahun 2016 akan mendapatkan sanksi administrasi dari Menteri Agraria dan Tata Ruang/Kepala Badan Pertanahan Nasional Republik Indonesia.

Ketentuan Pasal 44 ayat 1 Peraturan Pemerintah No. 24 Tahun 1997 menimbulkan masalah yuridis, yaitu ketentuan ini tidak dapat dilaksanakan oleh 
PPAT untuk membuat akta pembebanan hak sewa untuk bangunan atas tanah hak milik disebabkan berdasarkan Peraturan Pemerintah No. 24 Tahun 2016, PPAT tidak berwenang membuat akta pembebanan hak sewa untuk bangunan atas tanah hak milik. Jika PPAT tidak berwenang membuat akta pembebanan hak sewa untuk bangunan atas tanah hak milik, maka akta pembebanan hak sewa untuk bangunan atas tanah hak milik dapat dibuat oleh notaris berdasarkan ketentuan Pasal 15 UndangUndang No. 2 Tahun 2014 Tentang Jabatan Notaris. Hanya saja akta pembebanan hak sewa untuk bangunan atas tanah hak milik yang dibuat oleh notaris tidak dapat didaftarkan ke Kantor Pertanahan Kabupaten/Kota.

\section{Kesimpulan}

Hak sewa untuk bangunan terjadi atas tanah hak milik atau hak sewa untuk bangunan merupakan hak milik yang dibebani hak sewa untuk bangunan. Pembebanan hak sewa untuk bangunan atas tanah hak milik merupakan implementasi dari asas pemisahan horizontal, yaitu ada pemisahan antara pemilikan atas tanah dan pemilikan atas bangunan. Tanah merupakan milik dari pemilik tanah, sedangkan bangunan menjadi milik pemegang hak sewa untuk bangunan.

Akta pembebanan hak sewa untuk bangunan atas tanah hak milik yang ditetapkan oleh Pasal 44 ayat 1 Peraturan Pemerintah No. 24 Tahun 1997 tidak dapat dibuat oleh PPAT disebabkan berdasarkan Pasal 2 Peraturan Pemerintah No. 24 Tahun 2016, PPAT tidak berwenang membuat akta pembebanan hak sewa untuk bangunan atas tanah hak milik. Peraturan perundang-undangan tentang hak sewa untuk bangunan sebagaimana diperintahkan oleh Pasal 50 ayat 2 UUPA harus segera dibentuk agar memberikan jaminan kepastian hukum dan perlindungan hukum dalam pelaksanaan pembebanan hak sewa untuk bangunan atas tanah hak milik. Ketentuan Pasal 44 ayat 1 Peraturan Pemerintah No. 24 Tahun 1997 yang mengatur pembuatan akta pembebanan hak sewa untuk bangunan atas tanah hak milik oleh PPAT perlu ditinjau kembali disebabkan ketentuan pasal ini tidak dapat dilaksanakan oleh PPAT untuk membuat akta tersebut. 


\section{Daftar Bacaan}

\section{Buku}

Boedi Harsono, Hukum Agraria Indonesia Sejarah Pembentukan Undang-Undang Pokok Agraria Isi Dan Pelaksanaanya (Djambatan 2003).

Djuhaendah Hasan, Lembaga Jaminan Kebendaan Dan Benda Lain Yang Melekat Pada Tanah Dalam Konsepsi Penerapan Asas Pemisahan Horizontal (Citra Aditya Bakti 1996).

Eman, 'Asas Pemisahan Horizontal Dalam Hukum Tanah Nasional', Pidato Pengukuhan Jabatan Guru Besar (Fakultas Hukum Universitas Airlangga 2008).

Iman Sudijat, Hukum Adat Sketsa Asas (Liberty 1981).

Subekti, Pokok-Pokok Hukum Perikatan (Jakarta 1987).

—_, Hukum Perjanjian (Intermasa 2014).

Sudikno Mertokusumo, Hukum Dan Politik Agraria (Karunika 1988).

Urip Santoso, Perolehan Hak Atas Tanah (Kencana Prenada Media Group 2015).

—_, Hukum Agraria Kajian Komprehensif(Kencana Prenada Media Group 2017).

\section{Perundang-undangan}

Undang-Undang No. 5 Tahun 1960 Tentang Peraturan Dasar Pokok-pokok Agraria.

Undang-Undang No. 4 Tahun 1996 Tentang Hak Tanggungan Atas Tanah Beserta Benda-benda Yang Berkaitan Dengan Tanah.

Undang-Undang No. 42 Tahun 1999 Tentang Jaminan Fidusia.

Undang-Undang Nomor 28 Tahun 2002 Tentang Bangunan Gedung.

Undang-Undang No. 2 Tahun 2014 Tentang Jabatan Notaris.

Peraturan Pemerintah No. 24 Tahun 1997 Tentang Pendaftaran Tanah.

Peraturan Pemerintah No. 36 Tahun 2005 Tentang Peraturan Pelaksanaan UndangUndang Nomor 28 Tahun 2002 tentang Bangunan.

Peraturan Pemerintah No. 24 Tahun 2016 Tentang Peraturan Jabatan Pejabat Pembuat Akta Tanah. 